\title{
Ethnopedological Studies to Characterize Neosols at the Brazilian Semiarid Region
}

\author{
Jucirema Ferreira da Silva ${ }^{1}$, Jeane Cruz Portela ${ }^{1}$, Nildo da Silva Dias ${ }^{1}$, Cezar Augusto Medeiros Rebouças ${ }^{1}$, \\ Francisco Ernesto Sobrinho ${ }^{1}$, Miguel Ferreira Neto ${ }^{1}$ \& Gabriela Cemirames de Sousa Gurgel ${ }^{1}$ \\ ${ }^{1}$ Universidade Federal Rural do Semi-Árido, Mossoró, Brazil \\ Correspondence: Jeane Cruz Portela, Universidade Federal Rural do Semi-Árido, Av. Francisco Mota, 572, Bairro \\ Costa e Silva, CEP: 59.625-900, Mossoró, RN, Brazil. Tel: 55-(84)0-996-933-669. E-mail: \\ jeaneportela@ufersa.edu.br
}

Received: September 4, 2018

Accepted: December 21, $2018 \quad$ Online Published: March 15, 2019

doi:10.5539/jas.v11n4p536

URL: https://doi.org/10.5539/jas.v11n4p536

\begin{abstract}
The ethnopedological approach to soil characterization presents great challenges, since the understanding of the systems occurs through the knowledge acquired by the man in his coexistence with agroecosystems. The aim of the present research was to characterize the agricultural soils through morphological, physical and chemical analysis, using ethnopedological studies in the 'Santa Agostinha' Settlement Project, Caraúbas-RN, Brazil. Five areas were defined for study in the soil/landscape relation: i) area with cashew cultivation; ii) area of pasture; iii) area of crops in consortium; iv) agroforestry; and v) preserved forest, used as the reference. Participatory workshops, exchanges and classifications (from the locals and formal) were carried out with the analysis of the morphological, physical and chemical attributes of the studied soils in the layers of $0.00-0.10,0.10-0.20$ and $0.20-0.30 \mathrm{~m}$. The results of the ethicist classification, based on the attributes evaluation were: Quartzarenic latosol NEOSOL (cashew area); Regolitic euthrofic NEOSOL (pasture area); Ortic quartzarenic fragiudult NEOSOL (intercropping area); typical quartzarenic ortic NEOSOL (agroforestry area and typical hydromorphic quartzarenic NEOSOL that presented a close relation with the emicist classification (from the local people). The observation of the different soil types in the landscape, due to the stratification of the environments, allowed the growers to identify characteristics associated with soil potentials and restrictions and, consequently, the correct management to be adopted. The experiences of local growers in the participatory workshops provided an exchange of popular and scientific knowledge, as well as new perspectives of coexistence with the semiarid.
\end{abstract}

Kewwords: knowledge exchange, local growers, landscape

\section{Introduction}

Ethnopedological studies that highlight the importance of local community knowledge are scarce. However, is it important the dialogue between technical and traditional knowledge, especially aiming to strengthening the bases for the conservation of natural resources, notably soil and, according to Cabral et al. (2015), these studies are focused on soils genesis and morphology, but especially on agricultural and associated practices.

The growers knowledge is a result of their coexistence with agroecosystems, since they interact and modify the environment. Being closely linked to the soil, mainly by the agricultural activity, they develop a perception that allows to understand the operation of the environment in which they live and work. Therefore, it is a value that can not be disregarded in the evaluation of adopted soil management.

The grower, having minimal influences of modern technology, represents, better than any other individual, the results of adaptive effects throughout history. The grower, by nature, carries a set of techniques, attitudes and perspectives in relation to living with problems or even reducing them in a simpler way (Ernesto Sobrinho et al., 1983).

It is understood that scientific knowledge is supported by several studies and research, however, it may not always be appropriate to local realities (Audeh et al., 2011). Aiming the sustainability, ethnopedology, as a science, goal to unite the two forms of knowledge, dealing with different aspects, such as soil classification, use and management. 
In this context, the evaluation of soil and landscape attributes is an important tool for soil characterization and classification. The relevance becomes even greater when these studies are carried out in the light of ethnosciences, considering local social subjects as modifying agents of agroecosystems, whether contributing to their conservation or degradation.

The integrative processes generated through ethnopedological studies portray the importance of soil to people's lives in the most symbolic aspects, and may even act as a basis for the elaboration of public policies to support and conserve this resource widely used by modern societies.

Therefore, the aim of this study was to classify agricultural soils through morphological chemical and physical soil analysis, using ethnopedological studies in the Santa Agostinha Settlement Project, Caraúbas-RN, Brazil.

\section{Methodology}

The research was carried out in the Santa Agostinha Agrarian Reform Settlement Project (PA), located in the municipality of Caraúbas-RN, Brazil, from January 2013 to June 2015. Secondary activities were also carried out involving the PA Terra da Esperança, Tabuleiro Grande and Sitio do Góis, Located at Chapada do Apodi, RN, under the University Extension Program-PROEXT developed by the Federal Rural University of the Semiarid (UFERSA).

The municipality of Caraúbas is inserted in the West mesoregion of the Rio Grande do Norte State and at the Chapada do Apodi microregion and the climate, according to Köppen classification, is of the BSh type. The average rainfall is $776 \mathrm{~mm}$ per year, with the rainy season concentrated between February and May. The average annual temperature is $26^{\circ} \mathrm{C}$ and the mean air relative humidity is $70 \%$ (Alvares, 2013). The predominant soils of the municipality, according to Jacomine et al. (1971), has its origin in the Cretaceous, being represented by the group Apodi and Sandstone Assu. The Apodi group comprises rock formations derived from the Jandaíra limestone, which overlays the Sandstone Assur.

The predominant vegetation in the Brazilian semi-arid region is the hyperxerophilic caatinga, although the two types are found: the hyperoxeropophilic and hypoxerophilic caatinga. The first type is related to the caatinga that occurs in the central portion of the biome and the second in more peripheral areas.

In this sense, the ethnopedological study carried out in the settlement proposed to construct dialogues with the local families regarding soil use and occupation, understanding that the criteria adopted in the process of choosing the cultivation areas. The process was guided by knowledge little known by the academic community, that integrate a set of knowledge that, as a rule, are unnoticed, but identified and valued from the use of ethnopedology. The ethno-scientific research has its base supported by anthropological, social and linguistic factors, interacting directly with the way of thinking of the local people (Marques, 2001). Thus, the techniques used for approaches of ethnopedological studies are moving toward establishing links and empathy between local people and researchers, using tools of easy appropriation and systematization of knowledge.

The ethicist (science) and emicist (considering the local knowledge) approaches are described by Harris (2000) and Matos (2014) and are related to the knowledge generated in that space of study from the researcher point of view and the local knowlwdge approach, under the local growers perspective, establishing a dialectical relationship.

An exploratory survey was carried out to recognize the entire area that composes the perimeter of the settlement, in order to identify and establish some criteria and assignments of notes, for the sampling of the agricultural areas and the preserved forest adopted by the local growers. For this, participatory diagnostic tools were used, taking into consideration the agrosystems, as the basis of the study, stimulating the participation of local people from a systemic view (C. T. T. Machado \& A. T. Machado, 2006).

The initial proposal was to carry out a transversal survey to collect historical records of the areas under study, especially in the process of area expropriation, adopted agricultural practices and leveling information among local growers. This methodology has been elaborated in several studies that prioritize spaces of dialogue between local people and researchers. The transversal walk is accomplished by tracing a path along the cultivated areas of greater expression, which means, paths that allow a greater vision and analysis of the implanted agricultural subsystems, identifying the sources and uses of the natural resources.

It was performed the experiences exchange in the scope of execution of the University Extension Program among the settlements. The approach of the themes worked in the context of the exchanges and workshops was based on the cropping systems adopted in the agroecosystems taking into consideration the soil management and the use of the natural resources. 
Five soil profiles were sampled and georeferenced in the following study areas: i) cashew (Anacardium occidentale L.) area, which corresponds to approximately 5 ha, spacing between plants of 10x8 and 15 years of formation, located at the coordinates $5^{\circ} 53^{\prime} 30.3^{\prime \prime}$ south latitude and $37^{\circ} 10^{\prime} 25^{\prime \prime}$ west longitude, on top of flat elevation (interflow) with small differences. (ii) elephant grass (Peninsetum purpureum Schum.) area, which corresponds to approximately 2 ha, located at $5^{\circ} 41^{\prime} 42.86^{\prime \prime}$ south latitude and 37 $37^{\prime} 36.21^{\prime \prime}$ west longitude coordinates, with 13 years, spaced $0.50 \times 0.80 \mathrm{~m}$, in fields to facilitate cutting; (iii) the consortium area (maize, sweet potatoes and beans) located in an area of approximately 2 ha, with geographic coordinates of $5^{\circ} 20^{\prime} 33^{\prime \prime}$ south latitude and $37^{\circ} 04^{\prime} 34^{\prime \prime}$ west longitude, stream with an open V. Crops are implanted in the dam bed and are subject to flooding in the rainy season, making it necessary to carefully plan crop initiation.In the borders of the dam are located perennial crops and in the lower areas, short cycle crops. (iv) agroforestry area, with 3 ha and 8 years of vegetation management, located at $5^{\circ} 41^{\prime} 51^{\prime \prime}$ south latitude and $37^{\circ} 37^{\prime} 54^{\prime \prime}$ west longitude, in a ravine open upstream and downstream; (v) a preserved forest area of $3 \mathrm{ha}$, with no management at 15 years, located at the geographical coordinates of $5^{\circ} 27^{\prime} 75^{\prime \prime}$ south latitude and $37^{\circ} 06^{\prime} 41^{\prime \prime}$ west longitude on the third bottom of the stream elevation.

Characterization was performed to describe the profiles in the ethicist (scientific) and emicist (local growers) perspectives. The descriptions of soil profiles in an ethicist manner were carried out by the team of researchers and students of the UFERSA Graduate Program in Soil and Water Management, based on the Brazilian Soil Classification System (Santos et al., 2013).

In addition to the description of the environment and the morphological description of the profiles, soil samples were collected from the diagnostic horizons, being conditioned in plastic bags, processed in the laboratory (air dried fine soil) and analyzed for soil physical and chemical attributes for classification.

For the emicist (local growers) classification, three growers and three growers with knowledge of the area were selected, since they are considered reference in the settlement (Marques, 2002). They were chosen for their natural predisposition to experiment other forms of knowledge, such as through technologies of living with the semiarid region: agroecology, use of wastewater in agriculture and management of the caatinga and use of dams to capture rainwater.

Stratification of environments for key construction and classification of soils in the agricultural areas and in the preserved forest of the current study was used, according to the methodology proposed by Pertesen (1996). The key to identify environments was adjusted so that the criteria adopted for soil classification corresponded to attributes that best expressed the diagnostic characteristics for soil classification, related to local conditions, without generalization.

The physical analyzes were granulometry, by the pipette method and particle density using the volumetric method (Donagema et al., 2011).

The chemical analyzes were $\mathrm{pH}$ in water; $\mathrm{Ca}^{2+}, \mathrm{Mg}^{2+}, \mathrm{Na}^{+}$and $\mathrm{K}^{+}$content, electrolytic conductivity (EC), exchangeable $\mathrm{Al}^{3+}$, potential acidity $(\mathrm{H}+\mathrm{Al})$ and soil organic matter $(\mathrm{SOM})$. Based on the analyzes, the following indices were obtained: sum of bases (SB); effective cation exchange capacity $(\mathrm{t})$; cation exchange capacity at $\mathrm{pH}$ 7.0 (CTC); base saturation (V\%); exchangeable aluminum saturation $(\mathrm{m} \%)$ and percentage of exchangeable sodium (PST) (Donagema et al., 2011).

The results were interpreted according to the Manual of Recommendation for the Use of Corrective and Fertilizer in Minas Gerais (Ribeiro et al., 1999).

\section{Results and Discussion}

The presentation of the results follows a chronological order of activities based on transversal walks, participatory workshops and exchanges between settlements according to the ethnopedology.

It was observed that significant areas of the caatinga were cleared in order to obtain wood for charcoal, construction of the village and implantation of crop plots. These interventions, associated to the intensive grazing, intensified the erosive processes. Biodiversity was compromised, as well as reduced the soil production capacity and reduced the levels of artesian wells.

Matuk et al. (2017), developing ethnopedological studies in a quilombola community in the north of Minas Gerais State, Brazil, also report the instensification of some environmental problems which were a result of social changes in a context of modernization of the areas, being mentioned: the reduction of the level of the rivers and even the lakes disappearance. 
The participatory workshops provided a more investigative look at the characteristics of each type of soil to the local growers, who began to observe the stratification of environments and the soil quality evaluation from their experiences in the plantations.

Audeh et al. (2011) report that, in the evaluation of soil quality under an ethnopedological view, in family agriculture units, growers defined four classes of indicators, dividing them into morphological, physical, chemical and biological attributes, and that most of them refers to the physical attributes, considered more "visible" and easily altered by the adopted management.

Cabral et al. (2015), analyzing the traditional knowledge of local growers on the soils for the non-industrial manufacture of ceramics describe that the ceramist used morphological criteria to distinguish the different soil materials. These symbolic aspects and domains of belief guide the daily practice of the sites suitable for the development of agriculture and areas to be preserved.

In the morphological evaluation of the soil, the local growers attributed notes to soil color, texture, depth, consistency and microbial activity. In PA Santa Agostinha, these characteristics obtained high averages (above 5), meaning that, for them, these attributes contributed to fertility. Low fertility was related to the class of Neosols. Finato et al. (2015) studied the perception of farmers on soils in the city of Gravataí, Rio Grande do Sul, Brazil, and observed that they distinguish different types of soils in production units based on morphological and physical attributes such as soil texture, color and drainage. Color, texture and consistency were also used by potters in Altinho to designate different soil materials (Cabral et al., 2015).

Factors such as position in the landscape and depth were reported by farmers in defining environments with good or low soil quality; for them, soils located in less sloping areas are more productive because they are deeper and less susceptible to the erosive process. The different depths are determined by the curvature of the land, and, characteristically, ecosystems are directly controlled by the topography of the terrain, which, in turn, influences characteristics such as surface runoff (Chagas et al., 2013). According to a farmer's narrative, "where the soil is deeper, it produces better" (Audeh et al., 2011; Correia et al., 2007). These characteristics are directly associated to soil water dynamics, such as the infiltration and storage capacity. In the workshop held at PA Sítio do Góis, color and consistency were decisive in the identification of Vertisols class.

The workshops provided a more careful observation of the characteristics, potentialities and agricultural aptitude of soils. The parallel established between Neosols and Vertisols meant a starting point for growers to understand the importance of soil and vegetation management in environments, but with very diverse soils. According to Chagas et al. (2013), the formation factors are decisive for the different characteristics of the landscape, especially the source material and relief, which condition the formation of soils with different morphological, physical and chemical characteristics.

The exchanges between the PAs promoted an integration of the knowledge from the visualization of different pedogenetic environments, agroecosystems and development of agricultural activities. The exchange of knowledge among the local growers provided reflections and changes, understanding the different potentialities and constraints of the environments under study and the importance of the conservation of natural resources, with the implantation of areas in recovery systems, such as the agroecological unit, which is being used as a demonstrative pedagogical unit, a model for the affirmation of agroecology.

For the emicist (local growers) classification of soil profiles, the most relevant attributes perceived to characterize the soil were color and consistency. In the more superficial layers, the color "purple" prevailed and, in subsurface, "gray or yellow". The explanation given by a couple of growers, regarding the predominance of dark colors, is due to the lower location of these in the landscape. "This purplish color comes from somewhere else, from higher places, not from the soil in that corner, because if you dig deeper, you will see color changes; This purple color is where the soil is more strong. In places where it has this purple color, I see that plants do better there; In dry weather, 'fortitude' is still there, but it is weaker because the lack of water". The term fortitude of the soil refers, according to growerls, to the presence of organic matter and clay in the superficial layers of the soil.

The perception confirms the importance of the presence of organic matter to good conditions of plant growth and development. This is because organic matter is directly related to the physical, chemical and biological characteristics of the soil; at the same time as it contributes to the structuring of the soil (formation of stable aggregates), guarantees an energetic substrate for the population of organisms that, in turn, are responsible for the decomposition and, consequently, release of essential nutrients for the plants. 
Locall growers associate lowland soils, such as grassland, cultivated with elephantgrass and maize consortium area, sweet potatoes and beans as the "strong soil." This is classified by locals as caatinga soils (consortium area) and littoral sand (pasture area), located on the edge of the main reservoir.

Among the advantages obtained in the accomplishment of the crop consortium, we can mention the obtaining of a material with intermediate $\mathrm{C} / \mathrm{N}$ ratio phytomass compared to the single species, alteration of the proportions of the structural carbohydrates and lignins (Ranells \& Wagger, 1996; Heinrichs et al., 2011). This is directly related to the maintenance of crop residues on soil surface, moisture conservation and soil protection against erosion (Derpsch \& Calegari, 1985).

In this perspective, the quality of strong soil and weak soil suggest knowledge about the fertility of the areas, which is related to inorganic soil fractions (texture), color and the presence of organic matter. This subjectivity can be understood when the growers affirm that even areas where the soil is degraded, such as the agroforestry area, the management of the native vegetation, associated with the enrichment with the implantation of fruit trees, contribute to the increase of soil organic matter. This is due to aerial and subterranean residues, moisture, plant and flower diversity, supporting the apiculture activity, being the main source of income of the families of Santa Agostinha PA.

The application of soil management practices to the maintenance of vegetation cover, as well as the use of green manure, have advantages such as the recovery of degraded areas (Casalinho et al., 2007).

In the area known as "red sand," they considered it a "good soil for cashew tree and it is easy to see that the strong of the soil has the purple color on top and then turns red as it deepens. This purple color comes from leaves and cashew trees that fall, not being associated with the presence of gum", directly correlated to the presence of clay and silt.

Araújo et al., 2009, studying soil attributes in the interpretation of the Guarani Mbya Indians, have identified that the darker and less "sanding", the better the land for cultivation, according to the informants' reports.

In describing the profiles of the preserved forest area, the growers recognized the "white earth" as a "weak soil", "without force" and that the plants living in that area are resistant to semiarid conditions. Different from what happens in the cashew tree area, which is a "good soil", being this statement associated with the second largest income activity, cashew cultivation, where almond, sweet and honey are sold.

The reference that the growers couple made to the native forest is related to the species of cactaceae and bromeliáceas, predominant in these environments, being the black jurema indicative of successional stage of the caatinga and of degraded soils, adapted to the semiarid conditions, as well as the flowering of the black jurema contributes to the production of honey. In order to classify this area, the soil position in the landscape with a hydromorphic presentation was evaluated, being a quartzeneic typical hydromorphic neosol, differentiating from the area of Agroforestry, where the soil was classified as typical quartzarenic ortic neosol.

According to systematized statements in the study of the profiles and rapid field tests for dry, humid and wet consistency, it was reported that soil consistency is related to the presence or absence of gums in the soil (Table $1)$.

"If it does not bind, when the soil is dry it drips from the hand, if it binds it forms a soil clod and when it is half wet, the soil may even dirty the slippers, but then when it dries it leaves and if it binds it forms mass under the slippers. If it does not have bonds, the water will drop slightly. In winter you can walk on the red sand and white sand, but you can not walk on the edge of the reservoir where the sand is sticky, where the grass is located, because the feet sink. In the sand bank area, the water descends until it hits the hall." 
Table 1. Local grower's characterization (emicist) of Neosols, considering the position of the landscape at the Santa Agostinha settlement, Caraúbas-RN, Brazil

\begin{tabular}{|c|c|c|c|c|c|c|c|c|}
\hline \multirow{2}{*}{ Hor. } & \multirow{2}{*}{ Depth (m) } & \multirow{2}{*}{ Color } & \multicolumn{3}{|c|}{ Consistency } & \multicolumn{3}{|c|}{ Structure } \\
\hline & & & Humid & Dry & Wet & Dev. & Clas & Type \\
\hline
\end{tabular}

\section{Lower landscape}

Red sand (cashew tree area)

\begin{tabular}{|c|c|c|c|c|c|c|c|c|}
\hline A & $0.00-0.10$ & Red & do not aggregate & Untied & it is not sticky & don't form a mass & small & Not loamy \\
\hline $\mathrm{CA}$ & $0.10-0.35$ & Red & do not aggregate & Untied & it is not sticky & don't form a mass & small & Not loamy \\
\hline $\mathrm{C} 1$ & $0.35-1.10$ & Red & do not aggregate & Untied & it is not sticky & don't form a mass & small & Not loamy \\
\hline $\mathrm{C} 2$ & $1.10-2.10+$ & Red & do not aggregate & Untied & it is not sticky & don't form a mass & small & Not loamy \\
\hline \multicolumn{9}{|c|}{ Caatinga soil (intercropping area) } \\
\hline A & $0.00-0.20$ & purple & do not aggregate & Untied & it is not sticky & don't form a mass & small & Not loamy \\
\hline $\mathrm{E}$ & $0.20-0.42$ & gray & do not aggregate & Untied & it is not sticky & don't form a mass & small & Not loamy \\
\hline $\mathrm{C} 1$ & $0.42-0.73$ & gray & form soil clod & Linked & is sticky & form a mass & small & loamy \\
\hline $\mathrm{C} 2$ & $0.73-0.82+$ & gray & form soil clod & Linked & is sticky & form a mass & small & loamy \\
\hline \multicolumn{9}{|c|}{ Sticky sand (pasture area) } \\
\hline A & $0.00-0.07$ & purple & form soil clod & half tied & is sticky & form a mass & small & loamy \\
\hline $\mathrm{AC}$ & $0.07-0.17$ & gray & form soil clod & half tied & is sticky & form a mass & small & loamy \\
\hline $\mathrm{C} 1$ & $0.17-0.42$ & gray & form soil clod & half tied & is sticky & form a mass & small & loamy \\
\hline $\mathrm{C} 2$ & $0.42-0.82$ & gray & form soil clod & half tied & is sticky & form a mass & small & loamy \\
\hline $\mathrm{C} 3$ & $0.82-1.23+$ & gray & form soil clod & Half tied & is sticky & form a mass & small & loamy \\
\hline \multicolumn{9}{|c|}{ Untied soil (agroforest area) } \\
\hline A & $0.00-0.10$ & purple & do not aggregate & Untied & it is not sticky & don't form a mass & small & Not loamy \\
\hline $\mathrm{CA}$ & $0.10-0.20$ & yellow & do not aggregate & Untied & it is not sticky & don't form a mass & small & Not loamy \\
\hline $\mathrm{C} 1$ & $0.20-0.80$ & yellow & do not aggregate & Untied & it is not sticky & don't form a mass & small & Not loamy \\
\hline $\mathrm{C} 2$ & $0.80-1.45$ & yellow & do not aggregate & Half tied & is sticky & form a mass & small & loamy \\
\hline $\mathrm{C} 3$ & $1.45-1.90+$ & yellow & do not aggregate & Half tied & is sticky & form a mass & small & loamy \\
\hline
\end{tabular}

Higher landscape

Weak soil (preserved area)

$\begin{array}{lllllllll}\text { A } & 0.00-0.13 & \text { white } & \text { do not aggregate } & \text { untied } & \text { it is not sticky } & \text { don't form a mass } & \text { small } & \text { Not loamy } \\ \text { C1 } & 0.13-0.82 & \text { white } & \text { do not aggregate } & \text { untied } & \text { it is not sticky } & \text { don't form a mass } & \text { small } & \text { Not loamy } \\ \text { C2 } & 0.82-2.10+ & \text { white } & \text { do not aggregate } & \text { untied } & \text { it is not sticky } & \text { don't form a mass } & \text { small } & \text { Not loamy }\end{array}$

Note. Hor.: horizon; Dev.: development.

The local growers identified that the area located in lower portions of the landscape present a greater amount of silt and that one of the indicators of the expressive presence of this fraction brings the memory of "gum" (cassava starch) when it dries or "binds" when moist.

The term 'hall' is related to the presence of areas with fragipan. This characteristic was observed in soil profile where a clay translocation occurred, orienting, therefore, its classification in Ortic quartzarenic fragiudult neosol.

In the profile located in the consortium area, in general, the soils presented granular structure, 'with sticky sand and muddy soil, a mixture of mud and sand'. 'Hall' was a term used by the local growers to designate the presence of fragipan, an area used in the dry period for rainfed cultivation, due to the water storage caused by natural compactness.

Soil profiles were described for the morphological and physical characteristics for the ethicist classification. It was identified the predominance of brownish colors, varying between very light brown (when dry) and dark gray brown (when wet). The exception was observed for the ortic quartzarenic fragiudult neosol, where the color that prevailed was a yellowish red color. 
Table 2. Morphological atributes of neosols (ethicist characterization) of the Santa Agostinha Settlement Project, Caraúbas, RN, Brazil

\begin{tabular}{|c|c|c|c|c|c|c|c|c|c|}
\hline \multirow{2}{*}{ Hor. } & \multirow{2}{*}{ Depth (m) } & \multicolumn{2}{|c|}{ Color } & \multicolumn{3}{|c|}{ Consistency } & \multicolumn{3}{|c|}{ Structure } \\
\hline & & Humid & Dry & Humid & Dry & Wet & Dev. & Class & Type \\
\hline \multicolumn{10}{|c|}{ Quartzarenic latosol Neosol (cashew area) } \\
\hline A & $0.00-0.10$ & $5 \mathrm{YR} 4 / 6$ & $5 Y R 5 / 6$ & Mfr & $\mathrm{S}$ & $\tilde{n} \mathrm{Pl} / \tilde{\mathrm{n} P e}$ & $\mathrm{Fa}$ & $\mathrm{Pq}$ & $\mathrm{Gr}$ \\
\hline CA & $0.10-0.35$ & 5YR5/6 & 5YR6/6 & Mfr & $\mathrm{S}$ & $\tilde{\mathrm{n} P l} / \tilde{\mathrm{n} P e}$ & $\mathrm{Fa}$ & $\mathrm{Pq}$ & $\mathrm{Gr}$ \\
\hline $\mathrm{C} 1$ & $0.35-1.10$ & 5YR5/8 & 5YR6/8 & $\mathrm{Fr}$ & $\mathrm{Ma}$ & $\tilde{\mathrm{n} P l} / \tilde{\mathrm{n} P e}$ & Mo & $\mathrm{Mpq}$ & $\mathrm{Gr}$ \\
\hline $\mathrm{C} 2$ & $1.10-2.10+$ & $5 \mathrm{YR} 5 / 8$ & $5 Y R 6 / 8$ & Fr & $\mathrm{Ma}$ & $\tilde{\mathrm{n} P l} / \tilde{\mathrm{n} P e}$ & Mo & $\mathrm{Mpq}$ & $\mathrm{Gr}$ \\
\hline \multicolumn{10}{|c|}{ Ortic quartzarenic fragiudult Neosol (intercropping area) } \\
\hline A & $0.00-0.20$ & $10 \mathrm{YR} 5 / 3$ & $10 \mathrm{YR} 7 / 2$ & Fr & $\mathrm{Ma}$ & $\tilde{\mathrm{n} P l} / \tilde{\mathrm{n} P e}$ & Mo & $\mathrm{Pq}$ & $\mathrm{Gr}$ \\
\hline $\mathrm{E}$ & $0.20-0.42$ & $10 \mathrm{YR} 4 / 3$ & $10 \mathrm{YR} 7 / 3$ & Fr & $\mathrm{Ld}$ & $\tilde{\mathrm{n} P l} / \tilde{\mathrm{n} P e}$ & Mo & $\mathrm{Pq}$ & $\mathrm{Gr}$ \\
\hline $\mathrm{C} 1$ & $0.42-0.73$ & $10 Y R 4 / 3$ & $10 \mathrm{YR} 6 / 4$ & Fr & $\mathrm{Ld}$ & $\tilde{\mathrm{n} P l} / \tilde{\mathrm{n} P e}$ & Mo & Mpq & Sba \\
\hline $\mathrm{C} 2$ & $0.73-0.82+$ & $10 Y R 5 / 4$ & $10 \mathrm{YR} 6 / 4$ & M fir & $\mathrm{Md}$ & Lpl/Lpe & Fort & $\mathrm{Mpq}$ & Sba \\
\hline \multicolumn{10}{|c|}{ Regolitic euthrofic Neosol (pasture area) } \\
\hline A & $0.00-0.07$ & $10 \mathrm{YR} 3 / 3$ & $10 \mathrm{YR} 5 / 3$ & Mfr & $\mathrm{Ma}$ & $\tilde{\mathrm{n} P l} / \tilde{\mathrm{n} P e}$ & $\mathrm{Fa}$ & $\mathrm{Pq}$ & Sba \\
\hline $\mathrm{AC}$ & $0.07-0.17$ & $10 \mathrm{YR} 4 / 3$ & $10 \mathrm{YR} 5 / 5$ & Mfr & $\mathrm{Ld}$ & $\tilde{\mathrm{n} P l} / \tilde{\mathrm{n}} \mathrm{Pe}$ & Mo & $\mathrm{Mpq}$ & Sba \\
\hline $\mathrm{C} 1$ & $0.17-0.42$ & 10YR4/4 & 10YR5/4 & $\mathrm{Fr}$ & $\mathrm{Ld}$ & Lpl/Lpe & Mo & Mpq & Sba \\
\hline $\mathrm{C} 2$ & $0.42-0.82$ & 10YR4/4 & $10 \mathrm{YR} 5 / 4$ & Fr & $\mathrm{Ld}$ & Lpl/Lpe & Mo & $\mathrm{Pq}$ & Sba \\
\hline $\mathrm{C} 3$ & $0.82-1.23+$ & 10YR4/6 & $10 \mathrm{YR} 4 / 6$ & Fr & $\mathrm{Ld}$ & Lpl/Lpe & Mo & $\mathrm{Pq}$ & Sba \\
\hline \multicolumn{10}{|c|}{ Typical quartzarenic ortic Neosol (agroforestry area) } \\
\hline A & $0.00-0.10$ & $10 \mathrm{YR} 4 / 6$ & $10 \mathrm{YR} 5 / 6$ & Fr & $\mathrm{S}$ & $\tilde{\mathrm{n} P l} / \tilde{\mathrm{n} P e}$ & $\mathrm{Fa}$ & $\mathrm{Pq}$ & $\mathrm{Gr}$ \\
\hline $\mathrm{C} 1$ & $0.10-0.20$ & 10YR5/8 & $10 \mathrm{YR} 6 / 6$ & Fr & $\mathrm{S}$ & $\tilde{\mathrm{n} P l} / \tilde{\mathrm{n} P e}$ & $\mathrm{Fa}$ & $\mathrm{Pq}$ & $\mathrm{Gr}$ \\
\hline $\mathrm{C} 2$ & $0.20-0.80$ & $10 \mathrm{YR} 5 / 8$ & $10 \mathrm{YR} 6 / 6$ & Fr & $\mathrm{S}$ & $\tilde{\mathrm{n} P l} / \tilde{\mathrm{n} P e}$ & $\mathrm{Fa}$ & $\mathrm{Pq}$ & $\mathrm{Gr}$ \\
\hline $\mathrm{C} 3$ & $0.80-1.45$ & 10YR5/6 & $10 \mathrm{YR} 7 / 8$ & Fr & $\mathrm{S}$ & $\tilde{n} \mathrm{Pl} / \tilde{\mathrm{n} P e}$ & $\mathrm{Fa}$ & $\mathrm{Pq}$ & $\mathrm{Gr}$ \\
\hline $\mathrm{C} 4$ & $1.45-1.90+$ & 10YR7/4 & $10 \mathrm{YR} 8 / 3$ & $\mathrm{Fr}$ & $\mathrm{S}$ & $\tilde{\mathrm{n} P l} / \tilde{\mathrm{n} P e}$ & $\mathrm{Fa}$ & $\mathrm{Pq}$ & $\mathrm{Gr}$ \\
\hline \multicolumn{10}{|c|}{ Typical hydromorphic quartzarenic Neosol (preserved forest) } \\
\hline A & $0.00-0.13$ & 10YR6/3 & $10 \mathrm{YR} 8 / 3$ & Mfr & $\mathrm{S}$ & $\tilde{\mathrm{n} P l} / \tilde{\mathrm{n} P e}$ & $\mathrm{Fa}$ & $\mathrm{Pq}$ & $\mathrm{Gr}$ \\
\hline $\mathrm{C} 1$ & $0.13-0.82$ & 10YR6/4 & $10 \mathrm{YR} 8 / 3$ & Mfr & $\mathrm{S}$ & $\tilde{\mathrm{n} P l} / \tilde{\mathrm{n} P e}$ & $\mathrm{Fa}$ & Mpq & $\mathrm{Gr}$ \\
\hline $\mathrm{C} 2$ & $0.82-2.10+$ & 10YR6/4 & $10 \mathrm{YR} 8 / 4$ & Mfr & $\mathrm{S}$ & $\tilde{\mathrm{n}} \mathrm{Pl} / \tilde{\mathrm{n}} \mathrm{Pe}$ & $\mathrm{Fa}$ & $\mathrm{Mpq}$ & $\mathrm{Gr}$ \\
\hline
\end{tabular}

Note. Hor.: horizon; Dev.: development; Fr: friable; Mfr: Very friable; Ma: soft; Ld: slightly hard; D: hard; S: loose; Pe: sticky; Lpe: slightly sticky; ñPe: non-sticky Pl: plastic; Lpl: slightly plastic; ñPl: not plastic; Mo: moderate; Fa: weak; G: large; Me: medium, Pq: small; Mpq: very small; B: blocks; G: granular; Sba: Subangular.

It can be affirmed that there is predominance of grayish nuances due to the location in the landscape, which corresponds to the lowland areas. In these environments, there is elevation of the water table in part of the year, appearing the hydromorphism condition. In the hydromorphic environment, part of the iron is removed from these layers, specific conditions of the Regolitic euthrofic neosol and ortic quartzarenic fragiudult neosol.

No significant differences were observed in the humid consistency, except for the Ortic quartzarenic fragiudult Neosol in the humid soil condition, being classified as friable on the surface and extremely firm in subsurface.

For the dry soil, there was a predominance of loose surface consistency and soft in subsurface, with the Ortic quartzarenic fragiudult Neosol and Regolitic euthrofic Neosol that presented a soft consistency (surface), slightly hard and very hard (subsurface). This change in subsurface consistency appears to be a trend of the Neosols located in areas with lower levels (colluvium), where migration of clay from the soil surface occurs to underlying layers associated with the elevation of the water table with fragipan formations.

The wet consistency did nor demosntrated oscillations, with exceptions of the Regolitic euthrofic Neosol and ortic quartzarenic fragiudult Neosol, which were classified as slightly plastic and slightly sticky in subsurface.

For the soil structure the predominance of weak and moderate development was observed, with very small and small classes and granular structure for the Quartzarenic latosol Neosol, Typical hydromorphic quartzarenic Neosol and subangular block structure for Ortic quartzarenic fragiudult Neosol and and Regolitic euthrofic 
Neosol. It is important to observe that, in the absence of the predominance of the clay fraction, the adhesion and cohesion forces are inexpressive.

The profiles presented a sandy to sandy-loam textural classification, with a greater accumulation of clay in subsurface, in the ortic quartzarenic fragiudult Neosol, which had its classification as sandy clay loams (Table 3).

The silt decreased in subsurface of the Quartzeneic Quartzeneic Neosol and the Ortic quartzarenic fragiudult Neosol. The other soils (Regolitic euthrofic Neosol, Typical quartzarenic ortic Neosol and Typical hydromorphic quartzarenic Neosol) presented a small increase in depth.

Mendonça et al. (2013), when studying the pedological and geoenvironmental aspects of the soils of Viruá National Park, identified the formation of Quartzarenic Neosols that, as in the present study, presented essentially sandy horizons, as well as a soil drainage restriction possibly associated with the highest average surface silt content. The authors also describe these soils as not suitable for agricultural use because they are characteristically very poor.

The same does not occur in the Santa Agostinha PA area, where the Neosols are managed with agricultural purposes, including the supply of vegetal material on the soil surface, resulting in values of organic matter ranging from $10 \mathrm{~g} \mathrm{~kg}^{-1}$ (pasture area) to $13 \mathrm{~g} \mathrm{~kg}^{-1}$ (intercropping area).

There was increase of the clay fraction in subsurface, except for the Typical quartzarenic ortic Neosol (Agroforest area). The translocation of the clay fraction in the fragmental Typical quartzarenic ortic Neosol may be associated with its location in the landscape (open v-shape). Studies of Spera et al. (1999) demonstrate that the agricultural activities carried out in this class of soils have caused the loss of organic matter and clay, causing soil adisaggregation.

Cavalcante et al. (2013), studying Neosols in the municipality of São Vicente, Rio Grande do Norte State, observed that the clay content increased in subsurface and that this increase is probably due to the smaller size of the surface clay particles, which are easily transported by water and deposited in lower landscape locations.

Neves et al. (2011), conducting research on soil erosion losses in the Jaruru river basin in the State of Mato Grosso, observed that the Quartzarenic Neosols present a high risk of soil loss, which is due to slope and ramp length, accelerating the erosive process and, consequently, the soil degradation. 
Table 3. Distribution of particle size, textural classification and particle density of Neosols, in the agricultural areas and preserved forest in the diagnostic horizons, Santa Agostinha Settlement Project, Caraúbas/RN, Brazil

\begin{tabular}{|c|c|c|c|c|c|c|c|c|}
\hline \multirow{2}{*}{ Depth } & \multicolumn{3}{|c|}{ Sand } & \multirow{2}{*}{ Silt } & \multirow{2}{*}{ Clay } & \multirow{2}{*}{ Silt/Clay relation } & \multirow{2}{*}{ Texture classification } & \multirow{2}{*}{$\rho_{\mathrm{s}}$} \\
\hline & Coarse & Fine & Total & & & & & \\
\hline $\mathrm{m}$ & \multicolumn{5}{|c|}{ 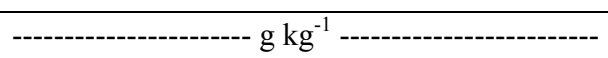 } & & & $\mathrm{kg} \mathrm{dm}^{-3}$ \\
\hline \multicolumn{9}{|c|}{ Quartzarenic latosol Neosol (cashew tree area) } \\
\hline $0.00-0.10$ & 630 & 271 & 901 & 68 & 31 & 2.19 & Sand & 2.43 \\
\hline $0.10-0.35$ & 701 & 220 & 921 & 52 & 27 & 1.95 & Sand & 2.51 \\
\hline $0.35-1.10$ & 662 & 227 & 889 & 56 & 55 & 1.02 & Sand & 2.46 \\
\hline $1.10-2.10+$ & 635 & 242 & 877 & 55 & 68 & 0.81 & Sandy loam & 2.47 \\
\hline \multicolumn{9}{|c|}{ Regolitic euthrofic Neosol (pasture area) } \\
\hline $0.00-0.07$ & 692 & 178 & 870 & 78 & 52 & 1.50 & Sand & 2.42 \\
\hline $0.07-0.17$ & 666 & 182 & 849 & 83 & 68 & 1.21 & Sand & 2.44 \\
\hline $0.17-0.42$ & 642 & 171 & 813 & 84 & 103 & 0.81 & Sand & 2.43 \\
\hline $0.42-0.82$ & 601 & 195 & 796 & 91 & 113 & 0.81 & Sandy loam & 2.43 \\
\hline $0.82-1.23+$ & 615 & 184 & 798 & 88 & 113 & 0.78 & Sandy loam & 2.44 \\
\hline \multicolumn{9}{|c|}{ Ortic quartzarenic fragiudult Neosol (intercropping area) } \\
\hline $0.00-0.20$ & 742 & 123 & 865 & 93 & 41 & 2.26 & Sand & 2.39 \\
\hline $0.20-0.42$ & 759 & 139 & 898 & 74 & 27 & 2.73 & Sand & 2.48 \\
\hline $0.42-0.73$ & 706 & 228 & 934 & 41 & 25 & 1.64 & Sand & 2.45 \\
\hline $0.73-0.82+$ & 591 & 169 & 761 & 44 & 195 & 0.23 & Sandy clay loam & 2.49 \\
\hline \multicolumn{9}{|c|}{ Typical quartzarenic ortic Neosol (agroforestry area) } \\
\hline $0.00-0.10$ & 570 & 323 & 893 & 84 & 23 & 3.60 & Sand & 2.50 \\
\hline $0.10-0.20$ & 608 & 297 & 905 & 74 & 21 & 3.50 & Sand & 2.59 \\
\hline $0.20-0.80$ & 586 & 301 & 887 & 85 & 28 & 3.00 & Sand & 2.59 \\
\hline $0.80-1.45$ & 599 & 289 & 888 & 91 & 21 & 4.30 & Sand & 2.55 \\
\hline $1.45-1.90+$ & 598 & 286 & 884 & 98 & 18 & 5.40 & Sand & 2.49 \\
\hline \multicolumn{9}{|c|}{ Typical hydromorphic quartzarenic Neosol (preserved forest) } \\
\hline $0.00-0.13$ & 669 & 259 & 928 & 57 & 15 & 3.80 & Sand & 2.49 \\
\hline $0.13-0.82$ & 668 & 258 & 925 & 55 & 20 & 2.75 & Sand & 2.50 \\
\hline $0.82-2.10+$ & 644 & 279 & 923 & 60 & 17 & 3.52 & Sand & 2.43 \\
\hline
\end{tabular}

Note. $\rho_{\mathrm{s}}$ : solids density.

For the silt/clay relation, subsurface oscillations were observed for the different profiles. This oscillation may be related to the material of origin, as well as its position in the landscape, where the relief acts with its convex concave formation. In this sense, the silt/clay ratio ranged from 0.23 to $5.4 \mathrm{~g} \mathrm{~kg}^{-1}$, with the lower values being located in the Ortic quartzarenic fragiudult Neosol at the lower limit and the upper ones located at the typical Typical quartzarenic ortic Neosol, corresponding to the intercropping and the agroforestry areas, respectively.

The silt/clay relation is an important parameter that indicates the degree of soil weathering. Thus, values taken as a basis for indicating highly weathered soils are $<0.6$ for sandy textured soils and $<0.7$ for clayey soils (Santos et al., 2013).

According to the chemical evaluations, it was observed a $\mathrm{pH}$ oscillation, with an elevation in the surface, with weak and moderate reaction on subsurface, from 6.60 to 4.72. EC values decreased in subsurface, with values that do not cause restrictions due to salinity, and are not a limiting factor for plant growth and development (Table 4). 
Table 4. Chemical attributes of the agricultural areas and in the forest preserved in the diagnostic horizons and their classification, in the Santa Agostinha Settlement Project, Caraúbas-RN

\begin{tabular}{|c|c|c|c|c|c|c|c|c|c|c|c|c|c|c|c|c|}
\hline Depth & $\mathrm{pH}$ & $\mathrm{EC}$ & SOM & $\mathrm{P}$ & $\mathrm{K}^{+}$ & $\mathrm{Na}^{+}$ & $\mathrm{Ca}^{2+}$ & $\mathrm{Mg}^{2+}$ & $\mathrm{Al}^{3+}$ & $(\mathrm{H}+\mathrm{Al})$ & SB & $\mathrm{t}$ & CEC & $\mathrm{V}$ & $\mathrm{m}$ & PST \\
\hline $\mathrm{m}$ & (water) & $\mathrm{dS} \mathrm{m}^{-1}$ & $\mathrm{~g} / \mathrm{kg}$ & \multicolumn{3}{|c|}{-------- $\mathrm{mg} \mathrm{dm}^{-3}$} & \multicolumn{7}{|c|}{ 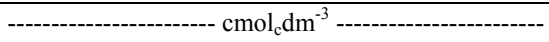 } & \multicolumn{3}{|c|}{------------ \% ------------ } \\
\hline \multicolumn{17}{|c|}{ Cashew tree (Quartzarenic latosol Neosol) } \\
\hline $0.00-0.10$ & 6.15 & 0.31 & 6.70 & 5.89 & 41.28 & 1.20 & 1.18 & 0.50 & 0.09 & 0.74 & 1.79 & 2.53 & 2.53 & 70.80 & 29.25 & 0.21 \\
\hline $0.10-0.35$ & 5.78 & 0.20 & 5.35 & 2.95 & 47.70 & 1.19 & 0.85 & 0.43 & 0.10 & 0.89 & 1.41 & 2.30 & 2.30 & 61.30 & 38.70 & 0.23 \\
\hline $0.35-1.10$ & 6.20 & 0.14 & 2.69 & 1.31 & 42.39 & 1.21 & 1.43 & 1.13 & 0.00 & 0.66 & 2.67 & 3.33 & 3.33 & 80.20 & 19.81 & 0.16 \\
\hline $1.10-2.10+$ & 5.23 & 0.14 & 1.25 & 1.97 & 44.47 & 1.21 & 0.45 & 0.53 & 0.39 & 0.97 & 1.10 & 2.07 & 2.07 & 53.10 & 46.86 & 0.25 \\
\hline \multicolumn{17}{|c|}{ Pasture (Regolitic euthrofic Neosol) } \\
\hline $0.00-0.07$ & 6.24 & 0.38 & 10.45 & 7.49 & 160.93 & 2.65 & 4.40 & 1.60 & 0.00 & 0.74 & 6.42 & 6.42 & 5.93 & 78.73 & 8.16 & 0.12 \\
\hline $0.07-0.17$ & 5.70 & 0.13 & 10.50 & 6.17 & 73.31 & 2.56 & 3.83 & 1.68 & 0.50 & 0.83 & 5.70 & 6.20 & 6.56 & 87.70 & 0.00 & 0.63 \\
\hline $0.17-0.42$ & 5.39 & 0.14 & 7.12 & 7.29 & 61.33 & 18.03 & 4.93 & 1.83 & 0.76 & 1.92 & 6.99 & 7.75 & 8.22 & 81.58 & 9.45 & 0.73 \\
\hline $0.42-0.82$ & 5.60 & 0.13 & 4.20 & 10.43 & 57.50 & 17.83 & 4.65 & 2.23 & 0.85 & 2.48 & 7.10 & 7.95 & 9.76 & 74.01 & 10.41 & 0.79 \\
\hline $0.82-1.23+$ & 5.50 & 0.21 & 3.43 & 7.77 & 74.33 & 17.54 & 4.78 & 2.15 & 0.78 & 2.10 & 7.19 & 7.97 & 9.02 & 77.64 & 10.13 & 0.85 \\
\hline \multicolumn{17}{|c|}{ Intercropping (Ortic quartzarenic fragiudult Neosol) } \\
\hline $0.00-0.20$ & 6.02 & 0.68 & 13.03 & 41.37 & 139.05 & 47.19 & 1.87 & 0.73 & 0.03 & 0.08 & 3.16 & 3.19 & 3.12 & 98.25 & 0.97 & 6.37 \\
\hline $0.20-0.42$ & 6.54 & 0.55 & 4.91 & 22.53 & 161.97 & 30.57 & 1.25 & 0.58 & 0.00 & 0.08 & 3.47 & 3.47 & 3.56 & 97.67 & 0.00 & 3.84 \\
\hline $0.42-0.73$ & 6.60 & 0.62 & 2.01 & 27.90 & 168.63 & 39.48 & 0.80 & 0.55 & 0.00 & 0.08 & 3.48 & 3.48 & 3.56 & 97.68 & 0.00 & 4.85 \\
\hline $0.73-0.82+$ & 6.17 & 0.65 & 3.03 & 30.96 & 54.85 & 35.91 & 2.20 & 1.78 & 0.00 & 0.08 & 5.10 & 5.10 & 5.18 & 98.34 & 0.00 & 3.24 \\
\hline \multicolumn{17}{|c|}{ Agroforest (Typical quartzarenic neosol) } \\
\hline $0.00-0.10$ & 6.43 & 0.72 & 16.10 & 7.53 & 127.00 & 3.91 & 1.78 & 0.53 & 0.00 & 0.00 & 2.64 & 2.64 & 2.64 & 100.00 & 0.00 & 0.65 \\
\hline $0.10-0.20$ & 5.20 & 0.23 & 6.00 & 5.72 & 63.00 & 4.10 & 1.00 & 0.43 & 0.20 & 1.53 & 1.60 & 1.80 & 3.13 & 50.30 & 11.83 & 0.45 \\
\hline $0.20-0.80$ & 4.74 & 0.22 & 5.20 & 4.00 & 44.85 & 5.60 & 0.43 & 0.41 & 0.65 & 2.15 & 1.09 & 1.74 & 3.23 & 33.41 & 37.99 & 0.77 \\
\hline $0.80-1.45$ & 4.72 & 0.15 & 2.84 & 3.33 & 40.06 & 3.91 & 0.40 & 0.55 & 0.60 & 2.10 & 1.05 & 1.65 & 3.16 & 33.30 & 36.85 & 0.54 \\
\hline $1.45-1.90+$ & 5.64 & 0.90 & 0.85 & 1.69 & 43.00 & 5.60 & 0.18 & 0.48 & 0.65 & 1.07 & 0.79 & 1.44 & 1.87 & 45.13 & 45.13 & 1.73 \\
\hline \multicolumn{17}{|c|}{ Preserved forest (Typical hydromorphic quartzarenic Neosol) } \\
\hline $0.00-0.13$ & 5.40 & 0.11 & 5.14 & 4.38 & 25.23 & 0.49 & 0.37 & 0.73 & 0.27 & 0.83 & 1.17 & 1.43 & 1.99 & 57.71 & 19.49 & 0.09 \\
\hline $0.13-0.82$ & 5.36 & 0.09 & 2.99 & 2.68 & 25.27 & 0.22 & 0.20 & 0.25 & 0.43 & 1.53 & 0.52 & 0.94 & 2.04 & 25.91 & 0.28 & 0.33 \\
\hline $0.82-2.10+$ & 5.40 & 0.08 & 1.19 & 3.16 & 22.32 & 0.22 & 0.10 & 0.20 & 0.38 & 0.74 & 0.36 & 0.73 & 1.10 & 36.27 & 0.35 & 0.62 \\
\hline
\end{tabular}

Note. $\mathrm{pH}$ : hidrogenionic potential; $\mathrm{CE}_{\mathrm{es}}$ : electrical conductivity in the saturation extract; $\mathrm{SOM}$ : soil organic matter; P: phosphorus; K: potassium; Na: sodium; Ca: calcium; $\mathrm{Mg}$ : magnesium; $\mathrm{Al}$ : aluminum; $(\mathrm{H}+\mathrm{Al})$ : potential acidity; SB: sum of bases; t: effective cation exchange capacity; T: cation exchange capacity at $\mathrm{pH}$ 7.0; V: base saturation; m: saturation by aluminum; PST: percentage of exchangeable sodium.

Soil organic matter (SOM) and soil $\mathrm{P}$ contents were low and decreased in subsurface, with more expressive surface values in the Typical quartzarenic neosol (Agroforest) and $\mathrm{P}$ in the intercropping área (Ortic quartzarenic fragiudult Neosol). This fact is related to the biomass of the areas, with more organic matter accumulation. These results can be attributed to the constant contribution of organic compounds in different stages of decomposition due to the diversity of plant species implanted in combination with the native Caatinga species.

The percentage of sodium saturation presented normal values, in the diagnostic horizons except for the Ortic quartzarenic fragiudult Neosol (intercropping area), classified as solodic (6.37 and 6.56\%). These high levels of sodium are due to the source material associated with poor drainage in this environment. In this area, an underground dam is installed and for technical reasons, are implemented in areas where there is a physical impediment to water maintenance in the system. The soils affected by salts present expressive horizontal and vertical variability in the physical and chemical attributes, occurring alterations from the pluvial regime of the region (Freire, 2007). The concentrations of the exchangeable bases $\left(\mathrm{Ca}^{2+}, \mathrm{Mg}^{2+}\right.$ and $\left.\mathrm{K}^{+}\right)$were low in the diagnostic horizons of the profiles under study, with the exception of $\mathrm{Na}^{+}$, which contributed to an increase of the contents, resulting in sum of bases above $50 \%$ (eutrophic), masking the soil fertility. It is necessary to consider the implementation of recovery projects, preferably using tolerant plants at moderate levels of salinity and sodium contents. The highest values for $\mathrm{K}^{+}$in the area $\left(160.93 \mathrm{mg} \mathrm{dm}^{-3}, 139.05\right.$ and $\left.127.00 \mathrm{mg} \mathrm{dm}^{-3}\right)$ were found in the areas of pasture, intercropping and agroforestry. According to Maluf et al. (2015), another important contribution of the maintenance of the organic residues in the soil surface is the increase of this nutrient availability, especially in sandy soils.

The soil CEC in the studied areas were considered medium and received influence of the $\mathrm{Na}^{+}$cátion, which contributed to the increase of the PST in the Ortic quartzarenic fragiudult Neosol. According to Ernesto Sobrinho 
(1980), these high levels of $\mathrm{Na}^{+}$can be justified by the presence of sodium plagioclase rocks in the formation of these soils, where the impermeable layer reduces leaching and the rate of alteration of the rock minerals.

In this sense, it is of fundamental importance to know the natural fertility of the areas destined to the agriculture development, especially in Neosolos, to not require high levels of production when the soils of the region are of low to medium fertility. The adoption of practices that involve diversity of botanical species and conservation practices can improve the condition of this soil with organic matter input. Studies related to the evaluation of agroforestry systems should take into consideration the local particularities regarding the climatic pattern, sampling time, soil type and position in the landscape, since soil attributes are dynamic and can be modified in time and space (Marchiori Junior et al., 2000).

In this perspective, the intercropping area, located in a lowland area (colluvium) and with a subterranean dam conructed due to this condition, demontrated a real possibility of the use of rainwater in the period of prolonged droughts. However, it is important to monitor the accumulation of salts around the perimeter of the dam and the use of salinity tolerant species in order to guarantee the nutritional supply of the implanted crops.

\section{Conclusions}

Local lgrowers are able to differentiate the soil classes, inferring their quality from associations with soil color, texture, depth of consistency.

The observation of the different soil types, due to the stratification of the environments, allowed the growers to identify characteristics associated with the potentials and restrictions of the soil and, consequently, the correct management to be adopted, with the choice of potential areas and species adapted to the local particularities.

Color and consistency were the basis of the criteria perceived by local growers in the emicist classification of soil profiles. Terms such as "purplish color", "yellow color" and "gray color" were used. The purple color was associated to a "strong" soil.

Local growers also demonstrated knowledge about soil fertility, suggesting the occurrence of a "strong soil" and "weak soil", associated with the presence of organic matter, soil moisture, color and texture, with an impact on yield.

The eticist classification identified the occurrence of Neosol classes that, at the most advanced categorical levels, differed according to the landscape position.

\section{Acknowledgements}

This study was financed in part by the Coordenação de Aperfeiçoamento de Pessoal de Nível Superior-Brasil (CAPES)-Finance Code 001, and the authors thank to the Soil and Water Management Graduate Program (PPGMSA) of the Semiarid Rural Federal University (UFERSA).

\section{References}

Alvares, C. A., Stape, J. L., Sentelhas, P. C., Gonçalves, J. L. M., Sparovek, G. (2013). Köppen's climate classification map for Brazil. Meteorologische Zeitschrift, 22(6), 711-728. https://doi.org/10.1127/0941-29 48/2013/0507

Araújo, J. L., Anjos, L. H. C., \& Pereira, M. G. (2009). Atributos do solo e distinção de pedoambientes para agricultura na terra indígena Mbya em Ubatuba (SP). Revista Brasileira Ciencia do Solo, 33, 1765-76. https://doi.org/10.1590/S0100-06832009000600025

Audeh, S. J. S., Lima, A. C. R., Cardoso, I. M., Casalinho, H. D., \& Jucksch, I. J. (2011). Qualidade do solo: uma visão etnopedológica em propriedades agrícolas familiares produtoras de fumo orgânico. Revista Brasileira Agroecologia, 6, 34-48.

Cabral, R. L., Alves, A. G. C., Ribeiro, Filho, M. R., Souza Júnior, V. S., Ribeiro, M. R., \& Santos, C. G. R. (2015). Peasant and scientific knowledge on planosols as a source of materials in the making of non-industrial pottery. Revista Brasileira Ciencia do Solo, 39, 303-13. https://doi.org/10.1590/01000683 rbcs20150719

Casalinho, H. D., Martins, S. R., Silva, J. B., \& Lopes, A. S. (2007). Qualidade do solo como indicador de sustentabilidade de agroecossistemas. Revista Brasileira Agrociências, 13, 195-203.

Cavalcante, J. S. J., Portela, J. C., Silva, M. L. do N., Silva, J. F. da., \& Arruda, L. E. V. de. (2013). Atributos físicos e químicos de solos em processo de sodificação no município de São Vicente-RN. Revista Agropecuária Científica no Semiárido, 9(4), 93-101. 
Cavalcante, J. S. J., Portela, J. C., Silva, M. L. N., Silva, J. F., \& Arruda, L. E. V. (2013). Atributos físicos e químicos de solos em processo de sodificação no município de São Vicente-RN. Revista Agropecuária Científica no Semiárido, 9, 93-101.

Chagas, C. S., Fernandes Filho, E. I., \& Bhering, S. B. (2013). Relação entre atributos do terreno, material de origem e solos em uma área no noroeste do estado do Rio de Janeiro. Revista Sociedade e Natureza, 25, 147-62. https://doi.org/10.1590/S1982-45132013000100012

Correia, J. R., Anjos, L. H. C., Lima, A. C. S., Neves, D. P., Toledo, L. O., Calderano Filho, B., \& Shinzato, E. (2007). Relações entre o conhecimento de agricultores e de pedólogos sobre solos: Estudo de caso em Rio Pardo de Minas, MG. Revista Brasileira Ciencia do Solo, 31, 1045-57. https://doi.org/10.1590/S010006832007000500021

Derpsch, R., \& Calegari, A. (1985). Guia de plantas para adubação verde de inverno. Londrina: IAPAR.

Donagema, G. K., Campos, D. V. B., Calderano, S. B., Teixeira, W. G., \& Viana, J. H. M. (1985). Manual de métodos de análise de solos (2nd ed.). Rio de Janeiro: Embrapa Solos.

Ernesto Sobrinho, F., Resende, M., Moura, A. R. B., Schaun, N., \& Rezende, S. B. (1983). Sistema do pequeno produtor norte-rio-grandense: A terra, o homem e o uso. Mossoró: Fundação Guimarães Duque/Escola Superior de Agricultura de Mossoró.

Finato, T., Nascimento, P. C., Beck, F. L., Tornquist, C. G., Caetano, L. A. M., \& Fedrizzi, T. Z. (2015). Percepções locais sobre os solos e seu uso no município de Gravataí, RS. Revista Brasileira Ciencia do Solo, 39, 915-23. https://doi.org/10.1590/01000683rbcs20140514

Freire, O. (2006). Solos das regiões tropicais. Fundação de estudos e pesquisas agrícolas e florestais (p. 288). Botucatu: FEPAF.

Heinrichs, R., Aita, C., Amado, T. J. C., \& Fancelli, A. L. (2001). Cultivo consorciado de aveia e ervilhaca: Relação C/N da fitomassa e produtividade do milho em sucessão. Revista Brasileira Ciencia do Solo, 25, 331-40. https://doi.org/10.1590/S0100-06832001000200010

Jacomine, P. K. T., Silva, F. B. R., Formiga, R. A., Almeida, J. C., Beltrão, V. A., Pessoa, S. C. P., \& Ferreira, R. C. (1971). Levantamento exploratório-Reconhecimento de solos do estado do Rio Grande do Norte (Boletim Técnico No. 21). Recife: Ministério da Agricultura/Sudene.

Machado, C. T. T., \& Machado, A. T. (2006). Roteiro para diagnóstico participativo de agroecossistemas: Propostas para avaliações com enfoque na agrobiodiversidade e em práticas agroecológicas. Planaltina: Embrapa Cerrados.

Machiori Junior, M., \& Melo, W. J. (2000). Alterações na matéria orgânica e biomassa microbiana em solos de mata natual submetido a diferentes manejos. Pesquisa Agropecuária Brasileira, 35(6), 1177-1182. https://doi.org/10.1590/S0100-204X2000000600014

Maluf, H. J. G. M., Soares, E. M. B., Silva, I. R., Neves, J. C. L., \& Silva, M. F. O. (2015). Disponibilidade e recuperação de nutrientes de resíduos culturais em solos com diferentes texturas. Revista Brasileira Ciencia do Solo, 39, 1690-1702. https://doi.org/10.1590/01000683rbcs20140657

Marques, J. G. W. (2002). O olhar (des) multiplicado. O papel do interdisciplinar e do qualitativo na pesquisa etnobiológica e etnoecológica. In M. C. M. Amorozo, L. C. Ming, \& S. P. Silva (Eds.), Métodos de coleta e análise de dados em etnobiologia, etnoecologia e disciplinas correlatas (pp. 31-46). Rio Claro: Coordenadoria de Área de Ciências Biológicas.

Matos, L. V., Ker, J. C., Cardoso, I. M., Lani, J. L., \& Schaefer, C. E. G. R. O. (2014). conhecimento local e a etnopedologia no estudo dos agroecossistemas da comunidade quilombola Brejo dos Crioulos. Revista Sociedade e Natureza, 497-510. https://doi.org/10.1590/1982-451320140308

Matuk, F. A., Schaefer, C. E. G. R., Simas, F. N. B., Pereira, T. T. C., Gjorup, D. F., \& Coelho, F. M. G. (2017). Ethnopedology of a Quilombola community in Minas Gerais: Soils, landscape and land evaluation. Revista Brasileira Ciencia do Solo, 41. https://doi.org/10.1590/18069657rbcs20160223

Mendonça, B. A. F., Fernandes Filho, E. I., Schaefer, C. E. G. R., Simas, F. N. B., Vale Júnior, J. F., Lisboa, B. A. R., \& Mendonça, J. G. F. (2013). Solos e geoambientes do Parque Nacional do Viruá e entorno, Roraima: Visão integrada da paisagem e serviço ambiental. Ciencia Florestal, 23, 427-42. https://doi.org/10.5902/ 198050989287 
Neves, S. M. A. S., Motinho, M. C., Neves, R. J., \& Soares, E. R. C. (2011). Estimativa da perda de solo por erosão hídrica na bacia hidrográfica do rio Jauru/MT. Revista Sociedade e Natureza, 23, 423-34.

Petersen, P. (1996). Diagnóstico ambiental rápido e participativo: Levantando informações e mobilizando a comunidade para um manejo sustentável das terras (Cadernos de Agroecologia). Rio de Janeiro, Brazil.

Ranells, N. N., \& Wagger, M. G. (1996). Nitrogen release from grass and legume cover crop monocultures and bicultures. Agronomy Journal, 88(5), 777-882. https://doi.org/10.2134/agronj1996.000219620088000500 $15 \mathrm{x}$

Ribeiro, A. C., Guimarães, P. T. G., \& Alvarez, V. H. (1999). Recomendação para o uso de corretivos e fertilizantes em Minas Gerais. Viçosa: Comissão de Fertilidade do Solo do Estado de Minas Gerais.

Santos, H. G., Jacomine, P. K. T., Anjos, L. H. C., Oliveira, V. A., Oliveira, J. B., Coelho, M. R., ... Cunha, T. J. F. (2013). Sistema Brasileiro de Classificação de Solos (3rd ed.). Brasília: Embrapa.

Spera, S. T., Reatto, A., Martins, E. S., Correia, J. R., \& Cunha, T. J. F. (1999). Solos areno-quartzosos no Cerrado: Problemas, características e limitações aos usos. Planaltina: Embrapa Cerrados.

\section{Copyrights}

Copyright for this article is retained by the author(s), with first publication rights granted to the journal.

This is an open-access article distributed under the terms and conditions of the Creative Commons Attribution license (http://creativecommons.org/licenses/by/4.0/). 